\author{
UNITED STATES \\ DEPARTMENT OF THE INTERIOR \\ GEOLOGICAL SURVEY \\ WASHINGTON 25, D. C.
}

AEC - $1169 / 5$

July 29, 1955

Mr. Robert D. Nininger, Assistant Director

Division of Raw Materials

U. S. Atomic Energy Commission

Washington 25, D.C.

Dear Bob:

Transmitted herewith are three copies of TEI-319, "Stratigraphy of the Morrison formation in part of Northwestern New Mexico," by V. L. Freeman and L. S. Hilpert, April 1955.

We are asking $\mathrm{Mr}$. Hosted to approve our plan to publish this report as a Survey bulletin.

Sincerely yours,

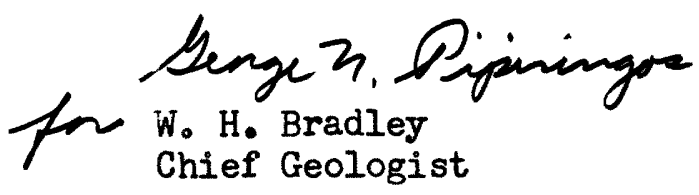

JAN 162001

MAY 5199 


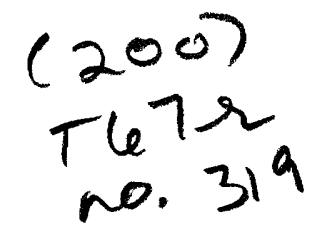

Geology and Mineralogy

This document consists of 46 pages. Series A

\author{
UNITED STATES DEPARTMENT OF THE INTERIOR
}

GEOLOGICAL SURVEY

\author{
STRATIGRAPHY OF THE MORRISON FORMATION IN PART \\ OF NORTHWESTERN NEW MEXICO*
}

$\mathrm{By}$

V. L. Freeman and L. S. Hilpert

April 1955

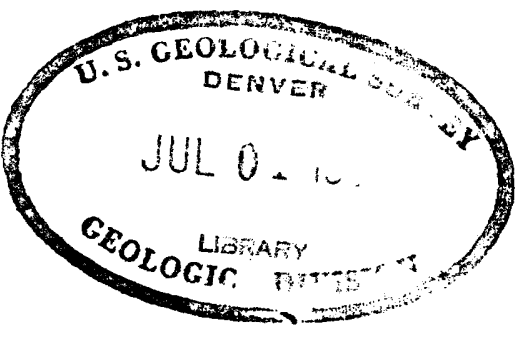

Trace Elements Investigations Report 319

This preliminary report is distributed without editorial and technical review for conformity with official standards and nomenclature. It is not for public inspection or quotation.

*This report concerns work done on behalf of the Division of Raw Materials of the U. S. Atomic Energy Commission. 


\section{GEOLOGY AND MINERALOGY}

Distribution (Series A)

No. of copies

Argonne National Laboratory

Atomic Energy Commission, Washington

Battelle Memorial Institute, Columbus

Carbide and Carbon Chemicals Company, Y-12 Area

Division of Raw Materials, Albuquerque

Division of Raw Materials, Butte

Division of Raw Materials, Casper

Division of Raw Materials, Denver

Division of Raw Materials, Hot Springs

Division of Raw Materials, Ishpeming

Division of Raw Materials, Phoenix

Division of Raw Materials, Salt Lake City

Division of Raw Materials, Washington

Dow Chemical Company, Pittsburg

Exploration Division, Grand Junction Operations Office

Grand Junction Operations Office

National Lead Company. Winchester

Technical Information Service, Oak Ridge

Tennessee Valley Authority, Wilson Dam

U. S. Geological Survey:

Fuels Branch, Washington

Geochemistry and Petrology Branch. Washington

Geophysics Branch. Washington

Mineral Deposits Branch, Washington

E. H. Bailey, Menlo Park

A. L. Brokaw, Grand Junction

N. M. Denson, Denver

M. R. Klepper, Spokane

A. H. Koschmann, Denver

J. D. Love, Laramie

L. R. Page. Washington

C. B. Read, Albuquerque

Q. D. Singewald, Beltsville

A. E. Weissenborn, Spokane

TEPCO, Denver

TEPCO, RPS, Washington, (including master) 


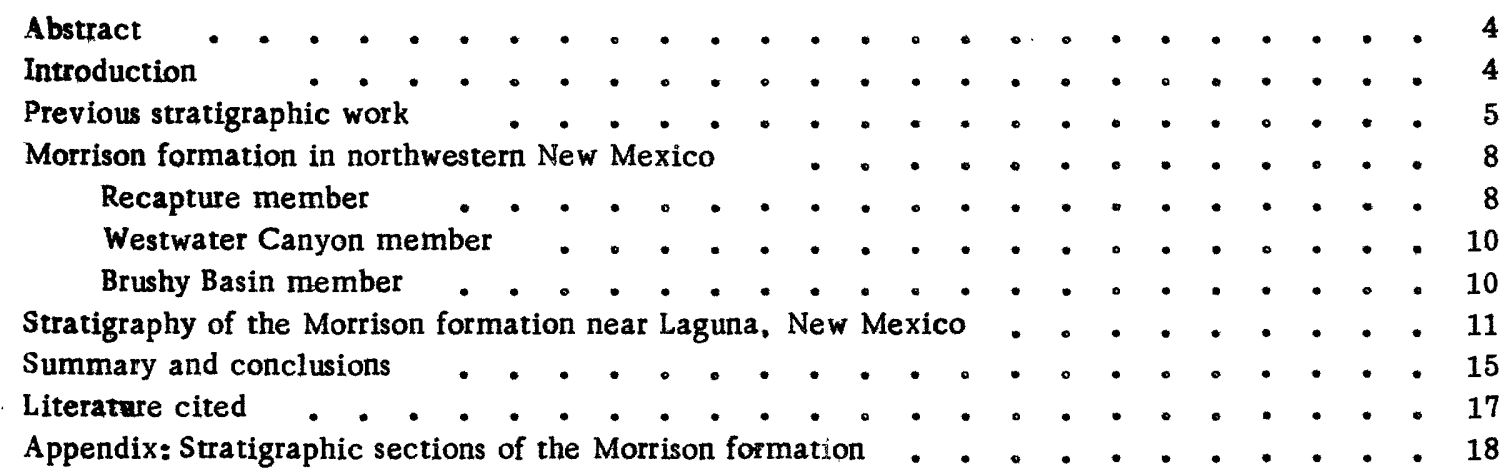

\section{ILLUSTRATIONS}

Figure 1. Index map of part of New Mexico and adjacent states showing localities referred to in text. . . . . . . . . . . . . . . . . . 6

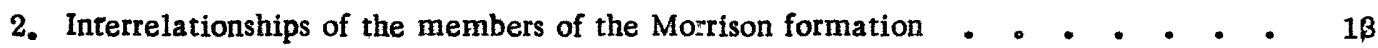

TAELES

Table 1. Nomenclature of the Morrison formation in northwestern New Mexico $\quad$ - $\quad$ - 9

2. Nomenclature of the Morrison formation in the Laguna area, New Mexico - . 12 


\title{
STRATIGRAPHY OF THE MORRISON FORMATION IN PART \\ OF NORTHWESTERN NEW MEXICO
}

By V. L. Freeman and L。 S. Hilpert

\begin{abstract}
A B S TRACT
In the summer of 1954 while investigating the uranium resources of northwestern New Mexico, the authors noticed that the stratigraphic nomenclature of the Morrison formation in use in the Laguna area was not consistent with that in use elsewhere in the region. A review of the literature led the authors to the agreement that the nomenclature currently in use elsewhere in the afea, such as near Grants, is satisfactory. This usage divides the Morrison formation into three members: in ascending order they are the Recapture member, the Westwater Canyon member, and the Brushy Basin member. These members may be recognized and have been correlated throughout northwestern New Mexico. In the Laguna area the Recapture. Westwater Canyon, and most of the Brushy Basin members, as correlated by the authors, are present in the stratigraphic interval that has previously been considered as Recapture. The sandstone previously considered as Westwater Canyon is in the authors! bpinion at the top of the Brushy Basin. This sandstone is of economic importance and is informally named the "Jackpile sandstone."
\end{abstract}

\section{INTRODUCTION}

The field work on which this report is based was done during the summer of 1954 when the authors were engaged in investigating the uranium resources of northwestern New Mexico on behalf of the Division of Raw Materials of the U.S. Atomic Energy Commission。 While studying the uranium potential of the various stratigraphic units, a discrepency between the nomenclature of the Morrison formation in the Laguna area and in other parts of northwestern New Mexico became evident. As correct correlations were a necessity in evaluating the resource potential of the stratigraphic units, the authors undertook a stratigraphic study to assure proper correlation. Eleven stratigraphic sections were measured in northwestern New Mexico, four sections measured by others were examined, and a review of the literature was undertaken. This paper reviews the names that haw been proposed for the members of the Morrison formation in northwest New Mexico, 
describes the members, and presents the results of the authors ${ }^{2}$ work in correlating the members near Laguna with adjacent areas. The work was aided by the cooperation of the staffs of the mining companies in the area and the U. S. Atomic Energy Commission. Use was made of stratigraphic sections measured by L. C. Cralg and T. E. Mullens of the U. S. Geological Survey.

\section{PREVIOUS STRATIGRAPHIC WORK}

The nomenclature of the Jurassic formations in northwestern New Mexico was summarized and a complete bibliography of the Jurassic literature was presented by Baker, Dane, and Reeside (1936, p. 43). This paper, together with a revision published in 1947 (Baker, Dane, and Reeside), is the standard reference on Jurassic stratigraphy in the region. In the earlier paper the Morrison formation in northwestern New Mexico included the Todilto limestone member at the base overlain in ascending order by a sandstone member and a shale member (Baker, Dane, and Reeside, 1936, table 8). In the revision, the Todilto limestone was removed from the Morrison formation (Baker, Dane, and Reeside, 1947, p. 1668). No attempt was made in these papers to subdivide the Morrison formation above the Todilto limestone into formal members.

The first subdivision of the Morrison formation on the Colorado Plateau was made by Lupton (1941) who gave the name Salt Wash sandstone member to a basal conglomeratic sandstone unit in east-central Utah. At Bluff, Utah (fig. 1), a massive sandstone that forms the cliffs a long the San Juan River and locally referred to as the Bluff șandstone, was considered by Baker; Dane; and Reeside (1936; p. 21)

4s a member of tha Morrison formation. Gregory (1938; : P. 58), in the same area, recognized four. members of the Morrison formation: the, Bluff sandstone member at the base overlain by thecspture: shale member, the Westwater Canyon sandstone member, and the Brushy Basin shale member.

In 1947 the U. S. Geological Survey started a study of the stratigrapty of the Morrison formation on the Colorado Plateau (Craig and others, 1951). The study resulted in the definition of the distribution of the members of the Morrison formation in the Colorado Plateau region. As this study centered on the then known Morrison uranium ore deposits in western Colorado and eastern Utah, the Morrison formation of northwestern New Mexico was not investigated in detail. Craig tentatively assigned the Bluff sandstone, 


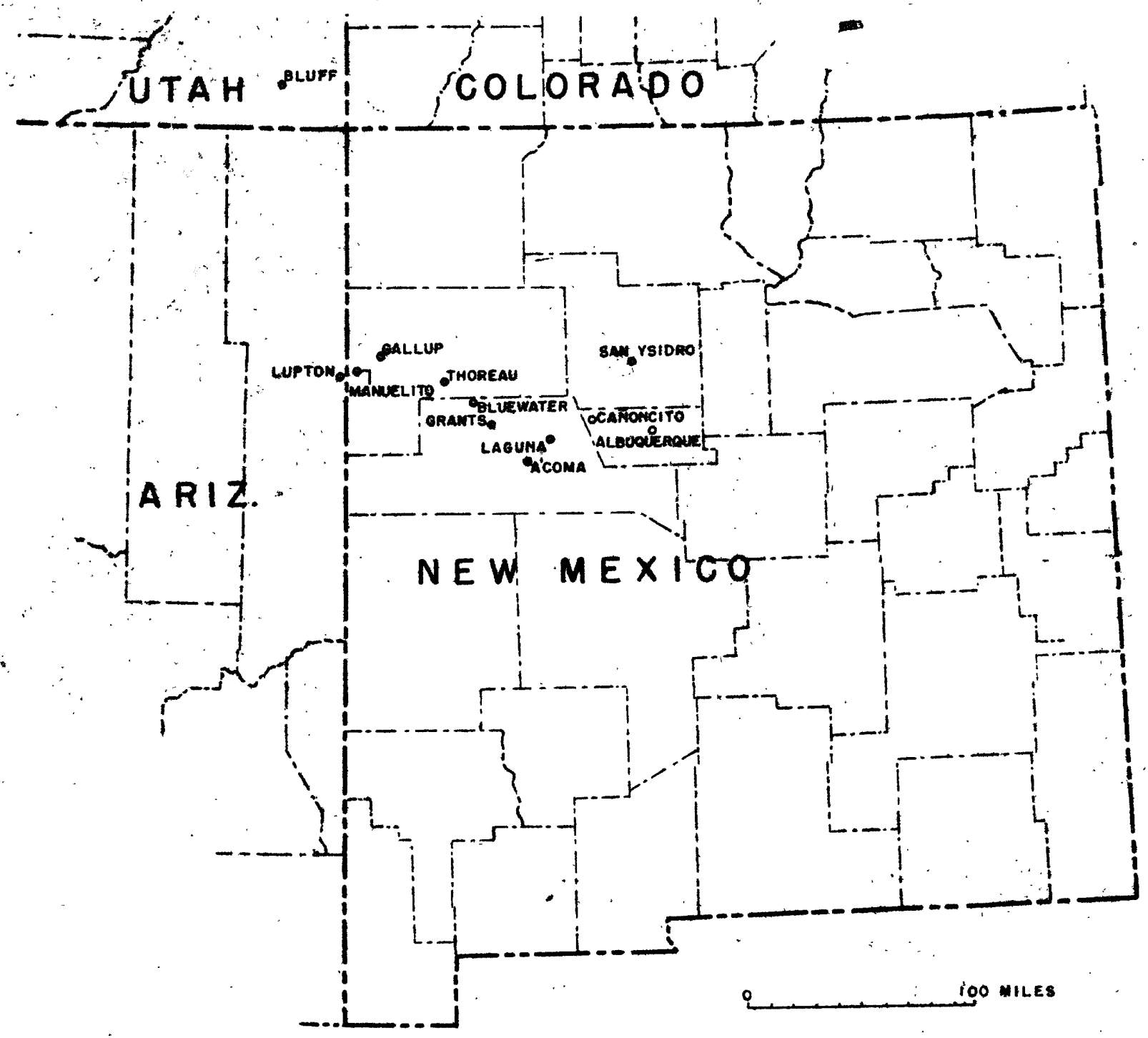


as a formation, to the upper part of the San Rafael group but retained as members of the Morrison formation in ascending order: the Salt Wash, Recapture, Westwater Canyon, and Brushy Basin. These assignments have been accepted by the Geologic Names Committee of the U. S. Geological Survey. The Salt Wash member was shown (Craig and others, 1951, p. 20 and 21) to extend from southeastern Utah a short distance into New Mexico, where it intertongces southwardly with the Recapture member and is absent from the rest of New Mexico. The remaining members of the Morrison formation, the Recaptipre, Westwater Canyon and Brushy Basin, were shown to extend to and beyond the Laguna area.

Before the extension of the Recapture, Westwater Canyon and Brushy Basin members of the Morrison formation into New Mexico, a set of informal member names was suggested by Kelley and Wood (1946) and adopted by Silver (1948) in the Laguna area. These were, in ascending order: the buff shale member, the brown-buff sandstope member, the white sandstone member, and the variegated shale member. Craig considered the buff shale member to be an equivalent of the Summerville formation and the brown-buff sandstone and the white sandstone members to be equivalents of the Bluff sandstone (Craig, personal communication). The variegated shale member apparently contains equivalents of the Recapture. Westwater Canyon and Brushy Basin members.

The discovery of commercial quantities of uranium ore in northwestern New Mexico in 1950, resulted in a study of the Jurassic sediments by the U. S. Atomic Energy Commission (Rapaport and others, 1952). The geologists of the U. S. Atomic Energy Commission recognized the presence of the Summerville formation and Bluff sandstone in the area of northwestern New Mexico east of Gallup (Rapaport and others. 1952, p. 20) and followed Craig*s (Craig and others, 1951) terminology for the Morrison formation (table 1). This terminology has been widely accepted by the personnel of the mining companies.

Smith (1951, p. $13 ; 1954$, p. 15) recently proposed a partly new set of names for the members of the Morrison formation (table 1). In the area near Thoreau, N. Mex., he divides the Morrison formation into the Chavez member at the base, stating that it may be equivalent to the Westwater Canyon member, and the Brushy Basin member at the top. The authors believe that the close similarity of the members of the Morrison in the Thoreau-Grants area with the members in southeast Utah could only be possible if they are continuous beneath the San Juan Basin. It, therefore, seems desirable to use the same 
terminology especially as it is in general use by the mining companies in northwest New Mexico, rather than adopt the new terminology of Smith. In summary, the Morrison formation of northwestern New Mexico is considered to consist of the Recapture member at the base. the Westwater Canyon member, and the Brushy Basin member. A summary of the terminology is presented in table 1.

\section{MORRISON FORMATION IN NORTHWESTERN NEW MEXICO}

In the belt of outcrop of the Jurassic rocks between Gallup and Albuquerque, the Morrison formation as uned here consists of three conformable members: the Recapture, Westwater Canyon, and the Brushy Basin. To the west, on the Navajo Indian reservation, several upper Jurassic units grade into a sand facies that has been named the Cow Springs sandstone (Harshbarger and others, 1951). At Lupton, Ariz.., the Recapture and Westwater Canyon members of the Morrison are recognizable although with difficulty. Farther to the south the Recapture member grades into the Cow Springs sandstone leaving only the Westwater Canyon as a recognizable member of the Morrison formation because the Brushy Basin member is missing probably due to pre-Dakota erosion. About 3 miles east of Gallup where the Jurassic section crops out on the flank of the Zuni Uplift, the Recapture is recognizaple although it is very sandy. A few miles farther east the Brushy Basin member appears beneath the Dakota sandstone;and in the area of concern in this report, the Morrison formation consists of the three members listed above.

\section{Recapture member}

The Recapture member in the Gallup-Albuquerque area ranges from about 20 to about 170 feet in thickness, in general thinning southward. It consists largely of grayish-red sandy claystone and clayey sandstone with limy nodules and white clean fine-to medium-grained sandstone in alternating units 5 to 10 feet in thickness. The clean sandstone beds are most common in the western part of the area and probably represent tongues of the Cow Springs sandstone. Clayey sandstone is the dominant rock type in the eastern and southern parts of the area. The Recapture in most of the area is conformable with the underlying Bluff sandstone, however, to the north near San Ysidro it rests directly upon the Summerville formation. 


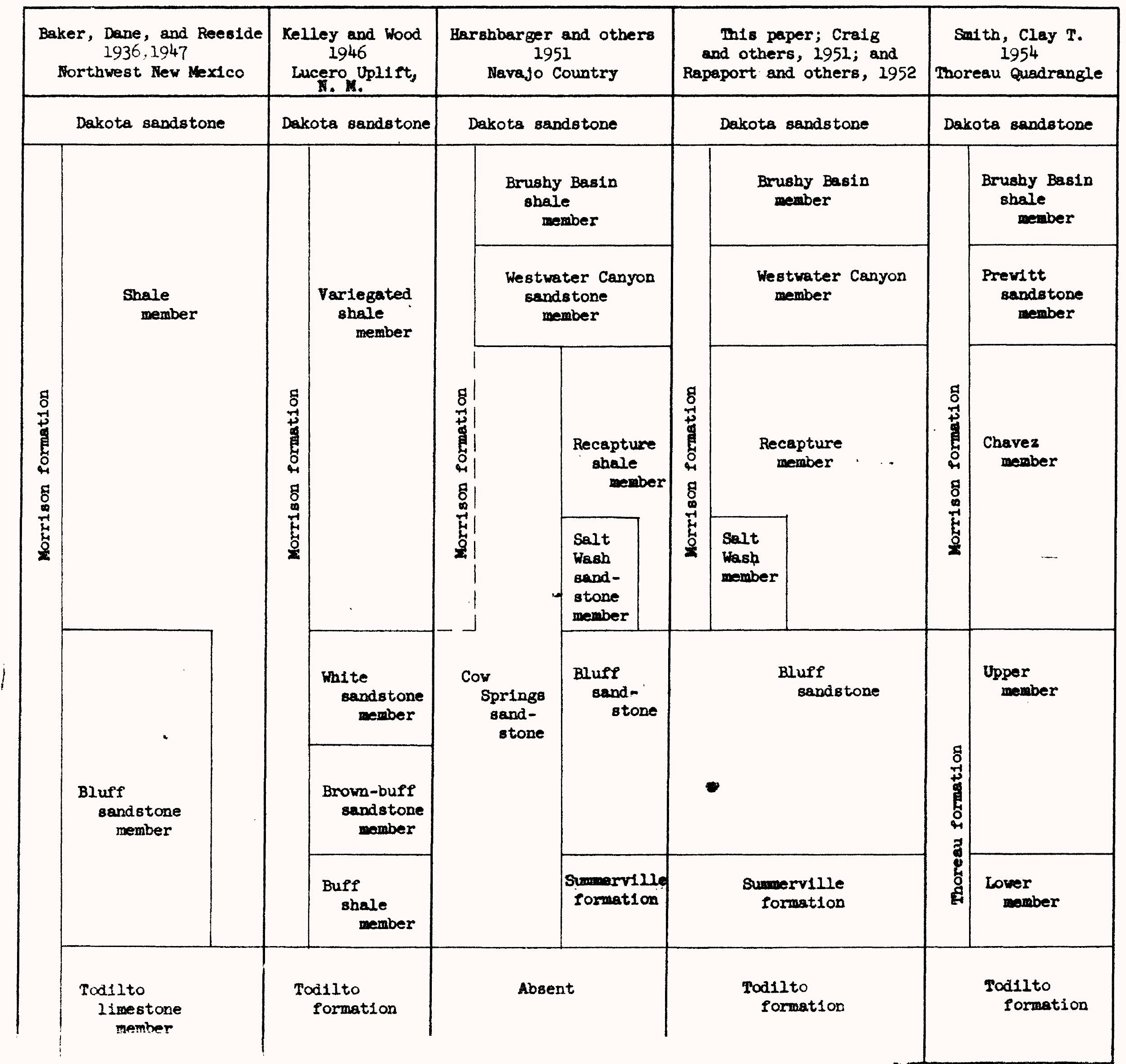


In general the upper part of the usually clean Bluff sandstone is clayey, but the contact with grayish-red clayey sandstone of the overlying Recapture member is sharply marked. In the Laguna area the Recapture member interfingers with the Bluff sandstone. On Haystack Butte, near Bluewater, the basal unit of the Recapture shale is a conglomeratic sandstone that rests on a slightly channeled surface cut into the Bluff sandstone; they are distinguished on the basis of grain size and type of crossbedding.

The Recapture member generally is overlain by the Westwater Canyon member from which it is easily distinguished. A few miles south of Laguna the Recapture is composed of clayey sandstone beds that, because of the absence of the Westwater Canyon, are directly overlain by Brushy Basin beds of similar lithology. Near Âcoma, farther to the southwest, the two members could not be separated with certainty.

\section{Westwater Canyon member}

The Westwater Canyon member ranges from about 50 to 190 feet in thickness in the GallupAlbuquerque area, but near Laguna it is locally absent. In general, the Westwater Canyon member thickens from the Laguna area toward Gallup to the west and toward San Ysidro to the'ndrth. The Westwater : . Canyon " is a yellowish-gray to light grayish-red, locally conglomeratic, finesigi conaserigrained. sandscone that is characterized by scour - ind-fill-typel. crossbedting and by arigitay grains of unweathered feldspar. Discontibuous lenses of grayish green sandy claystone are, present. The Westwater Canyon interfingers with both the underlying Recapture and the overlying Brushy Basin members.

Brushy Basin member

The thickness of the Brushy Basin member is largely determined by the amount of deformation and erosion prior to the deposition of the Dakota sandstone. The details of the pre-Dakota deformation are not known; but, in general, it consisted of northeastward tilting and local broad folding. Subsequent erosion resulted in a southwestward irregular thinning of the Brushy Basin. In northwest New Mexico the member ranges in thickness from a knife edge to about 370 feet. The Brushy Basin consists of partly variegated but dominately light greenish-gray, slightly swelling. locally sandy claystone with limy nodules. 
Thick sandstone units lithologically similar to the Westwater Canyon, thin hard green sandstone beds, and thin clayey limestone beds are rare to common. Pinkish-orange jasper commonly occurs, especially near the base, as crack fillings and as cement in thin sandstones. As the Brushy Basin and the Westwater Canyon interfinger, the contact between the members may be difficult to determine. The authors placed the contact at the base of the lowest recognizable Brushy Basin claystone and acknowledge that some of the sandstone beds placed in the Brushy Basin may laterally be equivalent to the Westwater Canyon member.

\section{STRA TIGRAPHY OF THE MORRIS ON FQRMATION NEAR LAGIUNA, NEW-MEXICD}

The Morrison formation in the Laguna area became of economic importance with the discovery of uranium in 1951. As a consequence a great deal of geologic work is in progress in the area. The nomenclature of the Morrison formation in general use is that used by the authors, but it is not being applied to the same stratigraphic units. Table 2 compares the terminology in recent use with that proposed by the authors. The correlation of the members of the Morrison formation between Laguna and adjacent areas is made difficult because of: (1) the similarity of the ore-bearing sandstone unit, informally called "Jackpile sandstone" in this paper, with the Westwater Canyon member; (2) the local absence of the Westwater Canyon: (3) the unusual thickness of the Brushy Basin member; and (4) the thinness and incomplete exposures of the Recapture membef.

Figure 2 shows the location of some of the measured sections studied and the relations of the members of the Morrison between the sections. The sections used are presented in the appendix. The Haystack Butte and Red Bluff sections are in the Grants area where there is general agreement on the nomenclature. At Haystack Butte the contact between the Westwater Canyon and the Brushy Basin is placed at the base of the lowest persistent claystone unit. Ledges of sandstone that could not be distinguished from the Westwater Canyon sandstone are present throughout the entire thickness of the Brushy Basin. Eastward toward the Red Bluff section the Westwater Canyon interfingers with the Brushy Basin and to a lesser extent with the Recapture resulting in a considerable thinning of the Westwater Canyon. Interfingering of the Recapture with the Bluff sandstone was not seen but may be present and may account for some thinning of the Recapture. The Morrison formation is not exposed in the arpa between the Red Bluff and Laguna sections. 
Table 2. Nomenclature of the Morrison formation

in the Laguna area, New Mexico

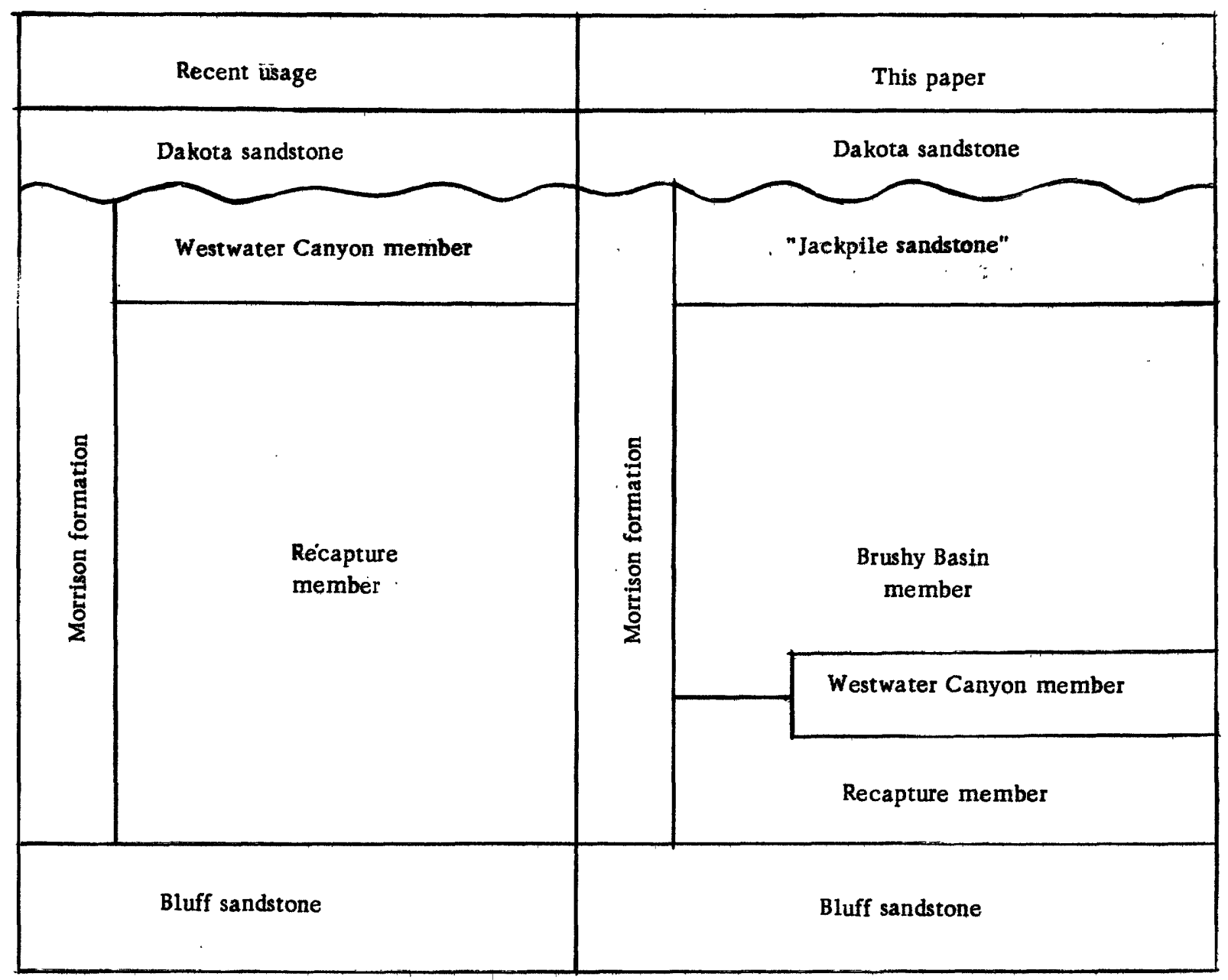

I 


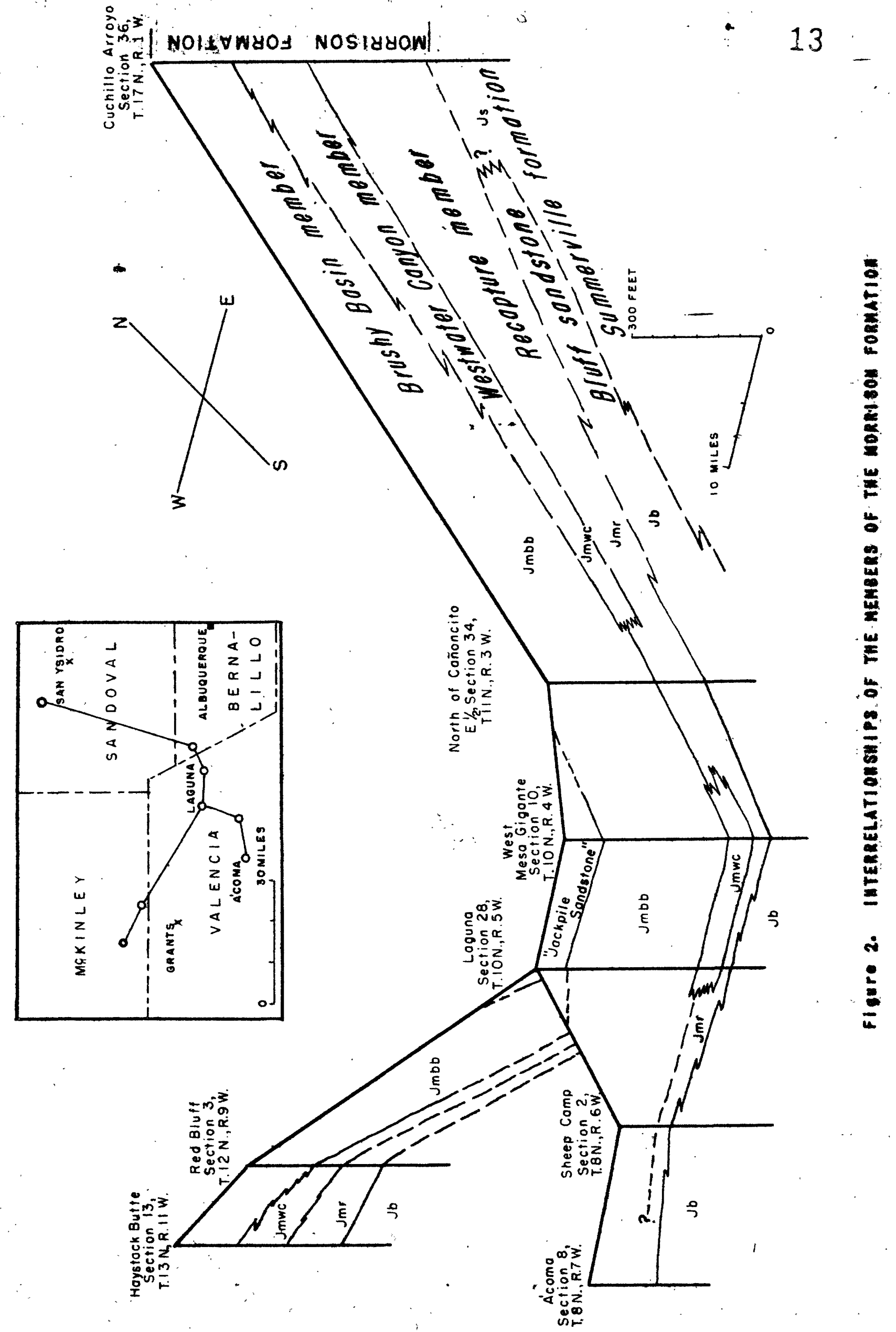


At the Laguna section, only the uppermost 29 feet of the Bluff sandstone is exposed. It is overlain by about 20 feet of reddish-brown and minor greenish-gray, very clayey sandstone with limy nodules that is typical of the Recapture member. Above the slope formed on the Recapture is a prominent ledge, about 55 feet thick, of the Westwater Canyon member. As no exposures of the Recapture exist between the Red Bluff and Laguna section, the manner of its thinning is not known. Silver (1948) showed that in this area the entire Jurassic thins southward by overlap against a Jurassic highland and the writers believe the thinning of the Recapture is ptobably due to the same cause.

The Westwater Canyon is very similar lithologically at the Laguna section and in the southeastern Utah area. It contains angular grains of unaltered feldspar, is moderately to poorly sorted, medium- tó coarse-grained, and is scour-and-fill crossbedded. These features are in marked contrast to the dominantly well-sorted, fine-grained, and sweeping crossbedded Bluff sandstone, that is not known to contain the angular grains of unaltered feldspar. South of Laguna the Westwater Canyon is not present; it likely disappears by interfingering with the Recapture and Brushy Basin members.

At the Laguna section the Brushy Basin member is about 370 feet thick. It consists of grayish-green slightly swelling clay-rich beds with some pinkish variegations near the base and lenticular sandstone units lithologically similar to the Westwater Canyon sandstone. The Brushy Basin in the Laguna area is similar to the Brushy Basin in the Grants area and in southeast Utah but distinctly different from the Recapture member in these areas. At the Laguna section the uppermost 65 feet of the Brushy Basin is the "Jackpile sandstone" of the authors. It is a very pale orange and locally white sandstone that is dominanty fine- to medium-grained with minor coarse grains at the base. Feldspar grains, as well as specks of a white clay mineral, probably kaolin, are present. The sandstone is characterized by scourand -fill crossbedding, but some parallel bedding, often marked by claystone partings, is present also. Towąr Ácoma, beyond the limit of the Westwater Canyon member, the Recapture and Brushy Basin members are considerably thinner (fig. 2). The Recapture-Brushy Basin contact can be picked with reasonable certainty as far southwest as the Sheep Camp section (fig. 2), but farther to the southwest the contact is indistinct. The Brushy Basin becomes more variegated, grayish-red colors are prevalent, and it is very similar to the Recapture. At the Ácoma section a reddish zone at the base of the Morrison may contains thin reddish zones. 
The West Mesa Gigante section is similar to the Laguna section; but, proceeding from the section southward along the west side of Mesa Gigante the Westwater Canyon member disappears in a few miles. It reappears for about a half a mile along the south face of the Mesa where it has a thickness of 58 feet; it does not reappear until about 3 miles north of Canoncito along the east face of the Mesa where it is 47 feet thick. At this locality, S $1 / 2$ sec, $27, T, 11 \mathrm{~N}_{0}, \mathrm{R}_{0} 3 \mathrm{~W}$, , the pipchout of the Westwater Canyon member is well exposed. In a distance of about 50 feet along the outcrop, the entire member, consisting of 47 feet of sandstone disappears by interfingering with sandy claystone beds of Recapture and Brushy Basin aspect (fig. 2). $\quad$ North of Cañoncito section, less than half a mile from the disappearance of the Westwater Canyon, the Recaptrue includes several sandstone beds of Westwater Canyon-type lithology. Between the Cañoncito area and the Cuchillo Arroyo section only the upper part of the Morrison is exposed locally. At Cuchillo Arroyo 170 feet of Westwater Canyon is well exposed in a vertical cliff. It interfingers at top and base with the Brushy Basin and Recapture respectively. The Recapture rests directly upon the Summerville formation from which it is distinguished with difficulty. The manner in which the Bluff sandstone has disappeared is not entirely known, but as the Bluff has been seen by the authbrs to interfinger with both the Recapture and Summerville formation, a gradual thinning by interfingering with these units is at least partially responsible.

\section{SUMMARY AND CONCLUSIONS}

The Morrison formation in the area of Laguna, N. Mex., consists of a 20 -foot unit at the base assigned to the Recapture member, a 55-foot sandstone assigned to the Westwater Canyon member, and a 370-foot unit assigned to the Brushy Basin member. The upper 65 feet of the Brushy Basin member is a sandstone that has been considered by others as the Westwater Canyon sandstone to which it is lithologically similar; the entire underlying Morrison, in consequence, was considered as Recapture shale. The members of the Morrison formation near Laguna are lithologically similar to the members in the area near Grants where there is general agreement of nomenclature, and in the San Ysidro area, where they are so typical as to preclude disagreement. The Recapture and the Westwater Canyon, however, are thinner near Laguna 
because of proximity to the edge of their areas of deposition; and the Brushy Basin is much thicker, probably because of less removal prior to the deposition of the Dakota sandstone.

The sandstone occupying the uppermost part of the Brushy Basin member has been traced from the Laguna section, in nearly continuous exposures, into the ore-bearing sandstone at the Jackpile mine of Anaconda Copper Mining Company. It ranges from a knife edge, where cut out by pre-Dakota (?) erosion, to about 175 feet in thickness at the Jackpile mine. Because of the economic importance of this sandstone, it has been informally named the "Jackpile sandstone" and is included in the Brushy Basin member. 


\section{LITERAT URE CITED}

Baker, A. A.. Dane, $\mathrm{C}_{j} \mathrm{H}_{+}$, and Reeside, J. B.. Jr., 1936, Corpelation of the Jurassic formations ofpparts of Utah. Arizona, New Mexico, and Colorado: U. S. Geol. Survey Prof. Paper 183.

1947. Revised correlation of Jurassic formatiohs of parts of Uhah, Arizona, New Mexico, and Colorado: Am. Assoc. Petrol. Geol. Bull., v. 31, p. 1664-1668.

Craig, L. C.. Holmes, C. N., Cadigan, R. A., Freeman, V. L., Mullens, T, E., and Weir, G. W., 1951 Preliminary report of the stratigraphy of the Morrison and related formations of the Colorado Plateau region: U. S. Geol. Survey TEI-180, U. S. Atomic Energy Comm. Tech. Inf. Service, Oak Ridge.

Gregory, H. E., 1938, The San Juan Country, a geographic and geologic reconnaissance of southeastern Utah: U. S. Geol. Survey Prof. Paper 188.

Harshbarger, J. W.. Repenning, C. A., and Jackson, R. L., 1951, Jurassic stratigraphy of the Navajo country: New Mexico Geol. Soc., Guidebook of the second field conference, p. 95-99.

Kelley, V. C., and Wood, G. H., 1946, U. S. Geol. Survey Oil and Gas Inv. Prelim. Map 47.

Lupton, C.T., 1941, Oil and gas near Green River, Grand County, Utah: U. S. Geol. Survey Bull. 541.

Rapaport, Irving, Hadfield, J, P.. and Olsen, R. H. , 1952, Jurassic rocks of the Zuni Uplift, New Mexico: U. S. Atomic Energy Comm., RMO-642.

Silver, Caswell, 1948, Jurassic overlap in western New Mexico: Am, Assoc. Petrol, Geol. Bull., v. 32, p. 68-81.

Smith, C. T., 1951, Generalized nomenclature chart for formation and member names used in road logs: New Mexico Geol. Soc., Guidebook of the second field conference, p. 13.

1954, Geology of the Thoreau Quadrangle, McKinley and Vafencia Counties, New Mexico: New Mexico Bur. of Mines and Mineral Res., Eull, 31. 
APPENDIX

TRATIGRAPHIC SECTIONS OF THE MORRISON FORMATION 
NEW MEXICO - VALENCIA COUNTY

LAGUNA section, NW-1/4, sec, 28, T, $10 \mathrm{~N}$, R $5 \mathrm{~W}$.

(Measured by L. C. Craig, V. L. Freeman, and T. E. Mullens)

Feet

Top of measured section

Dakota sandstone:

Sandstone, white (N9) $1 /$, to very pale orange (10YR8/2), weathering grayish orange (10YR7/4), fine- to medium-grained, well-sorted; composed of subrounded to rounded clear quartz with rare white accessory grains; well-cemented, calcareous; subparallel laminations filling shallow erosion troughs, thin- to medium-bedded, some ripple laminations. Conglomeratic sandstone near base, pebbles of gray and black chert, pebbles subangular to subrounded. Abundant plant impressions; some carbonaceous material, Unit forms vertical cliff . . . . . . . .

Morrison formation:

Brushy Basin member:

Sandstone, very pale orange (10YR8/2), locally white (N9) in upper part, predominantly fine- to medium-grained with rare coarse grains at base, well-sorted; composed of subangular to subrounded clear quartz with abundant pink feldspar grains and much interstitial kaolin, coarse grains are quartz, feldspar, granite, and rare red and brown chert; moderately well cemented; channeling with subparallel laminations filling erosion troughs; minor clay partings; unit forms ledgy slope with upper $16 \mathrm{ft}$. forming a vertical cliff. "Jackpile sandstone"

Claystone, grayish red (10R4/2) and light greenish gray (5GY8/1), very sandy (up to fine-grained); earthy weathering; slightly fissile; forms banded slope 
LAGUNA section--Continued

Morrison formation--Continued

Brushy Basin member---Continued

Feet

Sandstone, very pale orange (10YR8/2) to yellowish gray (5Y8/1), medium- to coarse-

grained, moderately sorted; composed of subrounded to rounded clear quartz with

abundant pink and white accessory grains; friable, weakly cemented; bedding not visible; forms steep slope..$\quad$. . . . . . . . . . . . .

Claystone, grayish red (10R4/2), very sandy (up to fine-grained); earthy weathering; slightly fissile . • . . . . . . . . . . . . . . . 11.8

Sandstone, with claystone and limestone near top; sandstone, grayish yellow (5Y8/a)

to white (N9), medium-grained with some very coarse grains at top, moderately

sorted; composed of subrounded quartz with common pink and white accessory

grains; very coarse grains at top are predominantly clear to white quartz, pink feldspar, and granite; well-cemented to friable; cross-laminations filling erosion troughs. Eight-

ft. claystone and limestone unit below 10-ft, top ledge same as in unit below.

Unit forms ledgy to rounded slope . . . . . . . . . . . . 33.7

Claystone, (90\%) and limestone (10\%). Claystone, dominantly light greenish gray

(5G Y8/1), with some yellowish gray $(5 Y 8 / 1)$ and at base pale red (5R4/2) to grayish red (10R4/2), silty to sandy (fine-grained). Limestone, very light gray (N8), weathers white (N9), dense to finely crystalline. Unit weathers to steep rubble-covered slope

Sandstone, conglomeratic, very pale orange $(10 \mathrm{YR} 8 / 2)$ to yellowish gray $(5 \mathrm{Y} 8 / 1)$, very

fine- to coarse-grained, poorly sorted; composed of subangular and subrounded clear quartz with abundant pink feldspar and uncommon white and green accessory grains. 
LAGUNA suction---Continued

Morrison formation---Continued

Brushy Basin member--Continued

Feet

Conglomerate consists mainly of tan, brown, gray, and red chert pebbles and granules averaging $3 / 4 \mathrm{in}$, with maximum 1-1/2 in. in diameter, and abundant pink feldspar and white to clear quartz grains averaging $1 / 8 \mathrm{in}$, with mpximum $1 / 2$ in. in diameter; cross-laminations filling erosion troughs; locally forms prominent ledge.

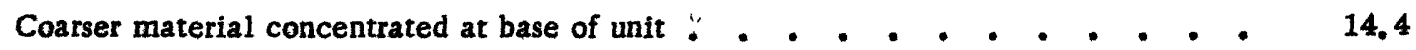
Claystone (85\%), sandstone (10\%), and limestone (5\%). Claystone, yellowish gray (5Y8/1) to light greenish gray (5G 8/1) and yellowish gray (5Y 7/2), slightly silty to slightly sandy (up to fine-grained); frothy weathering, forms pastel green and pink slope: Sandstone, light greenish gray (5G8/1) to very light gray (N8), very finegrained; forms beds up to $2 \mathrm{ft}$. thick, bedding not visible; weathers to slabby ledges. Limestone, very light gray (N8), dense; forms nodular beds to hackly ledges $1 \mathrm{ft}$. thick. Pink bands in claystone due to development of pink cherty spots.,.,$\quad 64.5$ Sandstone (65\%) and claystone (35\%); sandstone, yellowish gray (5Y8/1), fine- to mediumgrained, moderately sorted; composed of subangular to subrounded clear quartp with common red, green, and white accessory grains; well-cemented with coarse crystals of calcite; unit is lenticular, beds 1 to $5 \mathrm{ft}$. thick of wavy laminations and crosslaminations filling erosion troughs. Weathers to prominent ledges. Claystone, very light gray (N8), sandy (very fine- to fine-grained); hackly to earthy weathering, forms narrow slopes between ledges. Locally the sandstone contains dinosaur bones, gastroliths, and stringers of granule to pebble size reddish brown subangular chert . . . . 48.5 


\section{LAGUNA section--Continped}

Morrison formation--Continued

Brushy Basin member--C ontinaed

Fetet

Claystone (70\%), sandstone (15\%), and limestone (15\%). Claystone, variegated, dominantly yellowish gray ( $5 Y 8 / 1)$, to light greenish gray ( $5 G$ Y8/1) with thin beds of grayish purple (5P4/2) and grayish red purple (5RP4/2) near the base, sandy; in part calcareous; frothy weathering. Sandstone. yellowish gray $(5 \mathrm{Y} 8 / 1)$, fine- to very fine-grained, well-sorted; composed of subangular clear quartz with abundant pink and white and uncommon green accessory grains (pink probably feidspar); forms lenticular beds 1 to $10 \mathrm{ft}$. thick pinching out laterally within $300 \mathrm{ft}$, , cross-laminations filling erosion trough. Limestone, very light gray (N8), weathers white (N9); forms hackly to concretionary rubble-covered slope . . . . . . . . . . . . . . . . . . 58.0

Total Brushy Basin member . . . . . . . . . . . . . . 372.3

Westwater Canyon member:

Sandstone, yellowish gray (5Y7/2) to grayish yellow (5Y8/4), medium- to coarse-grained with rare grains up to $1 / 8$ in. . poorly sorted; composed of subangular clear quartz with common pink feldspar, uncommon red and white accessory grains; firmly cemented. calcareous; medium scale wedging cross-laminations; forms prominent cliff above ledgy slope below. A lenticular bed at base is $1 \mathrm{ft}$. thick, containing pebbles of red and gray chert and limy claystone. Limonite staining common . . . . . . . 56,7

Total Westwater Canyon member . . . . . . . . . . . 56.7

Recapture member:

Sandstone, clayey, and claystone, sandy, reddish brown (10R3/4) and greenish gray (5GY7/1),

fine- to medium-grained, poorly sorted; composed of subrounded stained quartz with uncommon orange and black accessory grains; calcareous; locally stained with limonite. At top of unit is zone of large $(1 \mathrm{ft}$.$) nodules of radiating calcite \quad . \quad+\quad . \quad+20.1$ 
LAGUNA section--Continued

Morrison formation--Continued

Recapture member--Continued

Feet

Total Recapture member . . . . . . . . . . . . 20.1

Total Morrison formation . . . . . . . . . . . . . . 449.1

Bluff sandstone (part):

Sandstone, clayey, grayish yellow (5Y8/4) to light greenish gray (5G Y8/1), medium-grained.

fair sorting; composed of subrounded grains of quartz with uncommon black and

orange accessory grains; calcareous; bedding obscure. Becomes increasingly clayey

upward. Limonite staining common. Weathers to gentle slopes or rounded

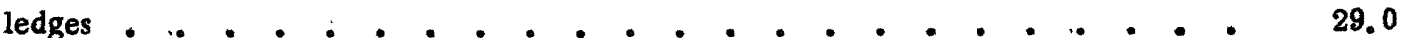

Base of measured section. 
1

ÁCOMA section, NW-1/4, sec. 8, T. $8 \mathrm{~N}, \mathrm{R}, 7 \mathrm{~W}$

(Measured by V. L. Freeman, November 1954)

Top of measured section.

Feet

\section{Dakota sandstone:}

Not measured or described.

\section{Morrison formation:}

Sandstone, clayey, dusky red (5R3/4) (30\%) and light greenish gray (5GY8/1) (70\%),

gypsiferous, some limy nodules present. Unit contains minor sandstone beds like

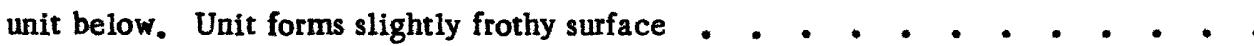

Sandstone, yellowish gray (5Y8/1), medium- to fine-grained, well-sorted, subrounded, grains of quartz with uncommon red and orange accessory grains; friable. calcareous; very lenticular beds with minor beds of argillaceous sandstone like below except entirely dusky red; crossbedding is contorted low angle and medium

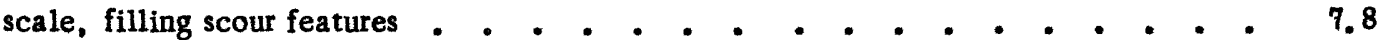

Sandstone, clayey, like top unit but $25 \%$ dusky red and $75 \%$ light greenish gray . . . $\quad 23.7$

Sandstone, white (N9), medium- to coarse-grained, conglomeratic, poorly sorted, grains of quartz with orange, red, and gray accessory grains, pebbles to $1 / 2 \mathrm{in}$. are of chert and clay (chert is mostly red with gray and green present); slightly friable, calcareous: crossbedding is low angle and medium scale, filling scour features . . . . .

Sandstone, clayey, dusky red (5R3/4) and light greenish gray (5GY8/1) in about equal amounts, fine-grained, poorly sorted, some limy nodules, minor amounts of sandy claystone and sandstone like below, forms slightly frothy surface 
(C)

ACOMA section - - Continued

Morrison formation--Continued

Feet

Sandstone, yellowish gray (5Y8/1), medium-grained, well-sorted, subrounded, grains

of quartz with uncommon red and orange accessory grains; friable, calcareous; very

lenticular beds with some argillaceous sandstone like below near center of unit;

Contorted crossbedding is low angle and medium scale, filling scour features $\quad . \quad$ - 12.0

Sandstone, clayey, dusky red (5R3/4), fine-grained, poorly sorted; forms slightly frothy

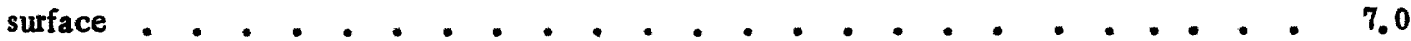

Note: At least lowest unit is probably equivalent to Recapture member Total Morrison formation _. . . . . . . . . . . . . 155.3

Bluff sandstone (part):

Sandstone, pale yellowish green (10G Y8/2), fine-grained, well-sorted, subrounded grains of quartz with rare orange and red accessory grains; friable, some calcareous cement, some unknown white cement; unit weathers into nounded knobs; bedding not

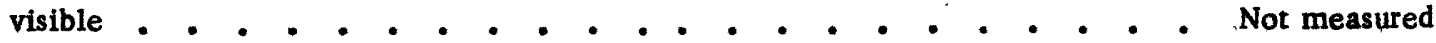

Base of section.

\section{NEW MEXICO - SANDOVAL COUNTY}

CUCHILLO ARROYO section, sec, $36, \mathrm{~T}, 17 \mathrm{~N}, \mathrm{R}, 1 \mathrm{~W}$

(Measured by L. C. Craig and V. L. Freeman, 1950)

Feet

Top of measured section.

Morrison formation (part):

Brushy Basin member (part):

Sandstone, very pale orange (10YR8/2) fine-grained, subangular, grains of clear quarta

with uncommon orangie and black accessory grains; hard, siliceous cement; lenticular

strata, forms prominent local capping ledge 
CUCHILLO ARROYO section---Continued

Morrison formation--Continued

Brushy Basin member--Continued

Feet

Claystone, light greenish gray (5G Y8/1), pale yellowish brown (10YR6/2), and pale reddish brown $(10 \mathrm{R} 5 / 4)$, silty to medium-grained sandy, with common 1 in. to $1 \mathrm{ft}$, beds of pale reddish brown (10R5/4) and greenish gray (5G6/1) silicified claystone, several light gray (N7) dense lenticular limestones; weathers to pastel green and pink; forms earthy to frothy slope . . . . . . . . . . . . . 58.3

Sandstone; tight greenisk gray (5G Y8/1) to yellowisk gray (5,Y8/1), fine-grained, sub*, angular, well-sorted, grains of clear quartz with common orange, green, and black accessory grains; massive, forms resistant ledge, is local highly lenticular unit . . . . . . . . . . . . . . . . . . . . 
CUCHILLO ARROYO section - Continued

Morrison formation--Continued

Brushy Basin member-- Continued

Feet

Claystone, light greenish gray (5G8/1) to light gray (N7) with minor pale reddish brown

(10R5/4) and pale yellowish brown (10YR4/2) at top. silty to very fine-grained sandy;

weathers to earthy light greenish gray slope with a few pale reddish biown bands

at top: one 6 in. lens of pale reddish brown silicified claystone or limestone near

top . . . . . . . . . . . . . . . . . . . . . 42.1

Total measured Brushy Basin member . . . . . . . . . . 105.3

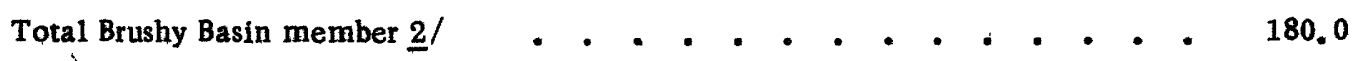

Westwater Canyon member:

Sandstone, light olive gray (5Y5/2) to yellawish gray (5Y8/1) to light greenish gray (5G Y8/1), very fine-grained at top and coarse-grained at bottom, predominantly medium-grained. subangular to subrounded, grains of clear quartz with rare orange and black accessory grains; medium scale cross-laminated, scour bedding. Note: Top four Westwater sandstone units appear thansitiớial tơ Brushy Basin member . . . . . . . 22.5

Claystone, pale grayish yellow (5Y9/4) to pale greenish gray $(5 G 6 / 1)$, slightly silty to medium-grained sandy; weathers to earthy slope . . . . . . . . . . 5,4 Sandstone, grayish orange (10YR7/4) to yellowish gray (5Y8/1), very fine-grained to medium-grained, subangular to rounded, poorly sorted, grains of clear quartz with rare orange and gray to black accessory grains; weakly cemented with streaks and bands of firm calcareous cement; medium scale cross-lamination indicated, scour bedding; forms ledgy slope $\quad$. . . . . . . . . . . . . 31.8

2/ Measured by E. H. Baltz, Jr., personal communication. 
CUCHILLO ARROYO section--Continued

Morrison formation--Continued

Westwater Canyon member--Continued

Feet

Claystone, greenish gray (5GY6/1), silty to slightly fine-grained sandy; weathers to earthy sandy slope, abundant very light gray (N8) dense to very fine-grained limestone nodules on surface

Sandstone, pale yellowish orange $(10 \mathrm{YR} 8 / 6)$ to yellowish gray $(5 \mathrm{Y} 8 / 1)$ to white, fineto medium-grained, subangular to subrounded, moderately sorted, grains of clear quartz with uncommon orange and white accessory grains, locally has specks of unknown white cement; medium scale cross-laminated, channeling; lateral to section contains thin lenses of greenish claystone - $_{-}$- $^{-}$- $^{-}$- $^{-}$-

85.5

Claystone, grayish red (10R4/2) and light greenish gray (5G 8/1) with minor very fine-

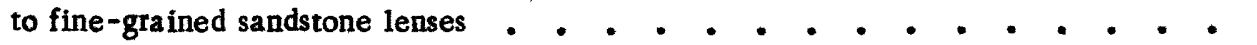

Sandstone, pale yellowish orange (10YR8/6) to yellowish gray (5Y8/1) to white (N9), fine-

to medium-grained, subangular to subrounded, moderately sorted, grains of clear quartz with uncommon orange and white accessory grains, locally has specks of unknown

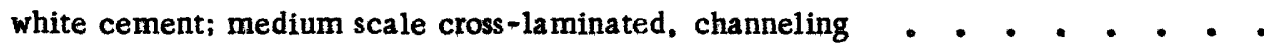

Recapture member:

Claystone, and sandstone (20\%). Claystone, very dusky red (10R2/2), silty to slightly finegrained sandy, structure partly masked, some thin irregular parallel beds; sandstone, light greenish gray (5GY8/1) to yellowish gray (5Y8/1), fine-grained, subangular. moderately to poorly sorted, some interstitial clay, grains of clear quartz with uncommon orange and black and minor green accessory grains; in structureless beds 6 in. to 3. $5 \mathrm{ft}$. thick; unit forms steep earthy slopes except under overlying cliff where it stands vertical 


\section{CUCHILLO ARROYO section---Continued}

Morrison formation --Continued

Recapture member--Continned

Feet

Sandstone and claystone, grayish orange pink (10R8/2) and very minor greenish gray (5G Y6/1),

fine- to medium-grained, subangular to rounded, moderately sorted, grains of clear quartz with abundant orange and black and rare green accessory grains; medium scale crom-lamination is indistinct; claystone, very dusky red $(10 \mathrm{R} 2 / 2)$ to grayish red $(10 \mathrm{R} 4 / 2)$, silty to slightly sandy, structureless to thin parallel bedded; unit weathers to steep ledgy slope of white and yellowish gray with grayish red bands , . .

Sandstone and claystane (25\%), sandstone, grayish orange pink (10R8/2), very fineto medium-grained, moderately sarted, subangular to subrounded, grains of clear quartz with common black and orange accessory grains; several biotire flakes noted; medium scale cross-laminations indistinct, locally channeling; claystone, very dusky red $(10 R 2 / 2)$ to grayish red (10R4/2), very slightly sandy up to fine-grained. finely micaceous, contains some thin sandstone beds, light greenish gray (5GY8/1) to grayish red (10R4/2), very fine- to fine-grained, subangular, moderately sorted, grains of clear quartz with abundant orange and black accessory grains; structureless; unit as whole weathers to pale red and grayish red ledgy slope.$+. \quad . \quad . \quad 96.5$ Sandstone, white to moderate orange pink (5YR8/4), very fine- to medium-grained, moderately sorted, subangular to subrounded, grains of clear quartz with abundant orange and common black and rare green accessory grains; medium scale crosslaminations indicated; unit weathers to sandy ledgy slope . . . . . . . . 
CUCHILO ARROYO section--Continued

Morrison formation---Continued

Recapture member--Continued

Feet

Claystone, very dusky red (10R2/2), grayishy purple (5P4/2) and grayish red (10R4/2);

very fine- to medium-grained sandy; sandstone, light greenigh gray (5G8/1) mottled grayish red (5R4/2), vezy fine- to fine-grained, rare medium grains, interstitial clay common, moderately to poorly sorted, subangular to rounded, grains of clear quartz with common orange, red, and black accessory grains; unit weathers to steep earthy slope . . . . . . . . . . . . . . . . . . . . 47.0 Total Recapture member $\quad$. . . . . . . . . . . . . 276.4 Base of measured section.

Summerville formation (part):

Claystone and sandstone; claystone, dark reddish brown (10R3/4) to pale reddish brown (10R5/4), pure to very sandy, very fine- to fine-grained, earthy weathering; sandstone, pale reddish brown (10R5/4) to grayish orange pink (10R8/2), very fine- to fine-grained, moderately sorted, subangular, weak to firm calcareous cement, grains of clear quartz with common black and orange accessory grains; unit weathers to earthy slope. . Not measured 


\section{NEW MEXICO - MCKINLEY COUNTY}

HAYSTACK BUTTE section, sec, 13, T, 13 N, $R, 11 \mathrm{~W}$.

(Measured by L. S. Hilpert and V. L. Freeman, August 1954)

Feet

Top of measured section .

Dakota sandstone (part):

Sandstone, light reddish orange (10R7/6), medium-grained, well-sorted, subrounded, grains of quartz with some white chert grains; friable, quartz overgrowths . . . . 40.0

Shale, carbonaceous. Some interbedded clayey sandstone, grayish red (5R4/2), mediumgrained, poorly sorted, angular to subrounded . . . . . . . . . . . 17.8

Morrison formation:

Brushy Basin member:

Poorly exposed. Local outcrops of claystone, silty and sandy, light greenish gray (5GY8/1);

and sandstone, pale yellowish brown (10YR6/2), medium-grained, poorly sorted, subangular to subrounded, grains of quartz with red and white accessory grains;

friable, calcareous cement and specks of white unknown cement - . - . . . . 67.2

Sandstone, slightly conglomeratic, pale yellowish brown (10YR6/2) with local greenish gray (5GY6/1), medium- to coarse-grained, poorly sorted, subangular to subrounded, grains of quartz with red and white accessory grains, granules and pebbles (to $3 / 4$ in.);

friable, calcareous cement and specks of unknown white cement; crossbedding is medium scale and low angle filling shallow erosional troughs . . . . . . . 2.7 Claystone, silty and sandy, very dusky red (10R2/2) and greenish gray (5G Y6/1) . $\quad$ • . $\quad .9 .6$ Sandstone, like second unit below . . . . . . . . . . . . . . . . . . . . 23.2 


\section{HAYSTACK BUTTE section--Continued}

Morrison formation--Continued

Brushy Basin member---Continued

Feet

Sandstone (at base) and claystone, silty; sandstone, very pale orange (10YR8/2), fine-grained, poorly sorted, subrounded, grains of quartz with orange, black, and white accessory grains, possibly some silica cement; claystone, dusky red (10R3/2) . . . . . . 6.0

Sandstone, pale yellowish brown (10YR6/2), very coarse-grained at base grading upward to medium-grained at top, poorly sorted, subangular to subrounded, grains of quariz with red and white accessory grains; very friable, calcareous near base, specks (1 to $3 \mathrm{~mm}$ across) of unknown white cement scattered throughout; crossbedding is medium scale and low angle filling shallow erosional troughs . . . . . . . . .

Claystone, silty, pale reddish brown (10R5/4), motted with yellowish gray (5Y8/1) . . 245 Total Brushy Basin member . . . . . . . . . . . . . 151.3

\section{Westwater Canyon member:}

Sandstone, grayish red (10R5/2) to light brown (5YR7/4) in lower part and grayish orange

(10YR7/2) with some limonite stain near top, poorly sorted, subrounded to rounded, grains of quartz with white, black, and orange accessory grains; locally calcareous in lower part; crossbedding is large scale and low angle filling shallow erosional troughs; mud pads and partings near base; this unit forms a prominent cliff . . . . . . 106.0 Total Westwater Canyon member . . . . . . . . . . . 106.0

Recapture member:

Sandstone, very clayey, dark reddish brown (10R3/4) and light greenish gray (5GY8/1), fine-grained, poorly sorted with some coarse grains, subrounded, grains of quartz with orange, red, and black accessory grains; very calcareous near middle . . . . . $\quad 2.5$ 


\section{HAYSTACK BUTTE section---Continued \\ Morrison formation--Continued \\ Recapture member--Continued}

Feet

Sandstone, yellowish gray (5Y8/1) and light olive gray (5Y6/1), fine-grained, well-sorted, subrounded, grains of quartz with orange and black accessory grains; slightly calcareous, locally clayey; bedding obscure . . . . . . . . . . . . . .

Sandstone, very clayey, dark reddish brown (10R3/4) to grayish red (5R5/2) with interbeds of pale olive (10Y6/2) near top, medium-grained, poorly sorted, subrounded, grains of quartz with orange and black accessory grains; calcareous with nodules near top. .

Sandstone, very light greenish gray (5G Y9/1) to light pinkish gray (5YR9/1), fine- to medium-grained, poorly sorted, subrounded, grains of quartz with orange accessory grains; friable, calcareous; bedding obscure . . . . . . . . . . . 11.2

Sandstone, very clayey, dark reddish brown (10R3/4), fine-grained, poorly sorted, subrounded . . . . . . . . . . . . . . . . . . .

Sandstone, light yellowish gray (5Y9/1), medium- to coarse-grained, moderately sorted, subrounded to rounded, grains of quartz with white, orange, and black accessory grains; friable, slightly calcareous; at base are granules and pebbles (to 1/2 in.) of red, black, and green chert; bedding mostly obscure, some crossbedding is medium scale, low angle, and some is straight in tabular sets . . . . . . . . . . . .

Sandstone (75\%) and claystone, sandy; sandstone, yellowish gray (5Y8/1) and pinkish gray (5YR8/1), fine-grained, moderately sorted, rounded, grains of quartz with orange and black accessory grains, locally green clay pods in sandstone at base. locally calcareous; claystone, pale yellowish green (10GY7/2) with mottling of dark reddish brown 
HAYSTACK BUTTE section--Continued

Morrison formation--Continued

Recapture member--Continued

Feet

Claystone, sandy, like second unit below, contains some thin sandstone beds near top . .

6.9

Sandstone, light yellowish gray (5Y9/1), medium-grained, poderately sorted, subrounded, grains of quartz with orange, red, and black accessory grains; very friable, calcareous especially near top and base; rare scattered pebbles near base; bedding obscure . . . . . . . . . . . . . . . . . . .

Claystone, sandy, mottled dark grayish red (10R3/2) and greenish gray (5G Y7/1),

calcareous. Near middle of unit is $8 \mathrm{in}$, bed of sandstone, greenish gray (5G Y7/1),

very fine-grained; friable, calcareous; thin parallel laminations . . . . . . . 7.0

Sandstone, pale red (10R6/2) and pinkish gray (5YR8/1), medium-grained with scattered

granules and pebbles (to $1 \mathrm{in.}$ ) locally concentrated along laminae; moderately to

poorly sorted, rounded; grains of quartz with orange, red, black, and green

accessory grains; very friable, calcareous; claystone parting about 7-1/2 ft. above

base; bedding mostly parallel but near base is cross-bedding of medium to large scale

and low angle that fills shallow erosional troughs . . . . . . . . . . 44.4

Total Recapture member . . . . . . . . . . . . . . 1332

Bluff sandstone:

Sandstone, moderate orange pink (10R7/4) to light brown (5YR7/4), fine-grained, well-

sorted, subrounded, grains of quartz with orange accessory grains; friable, calcareous;

crossbedding is large scale and low angle in tabular sets; forms nearly vertical

cliff

Not measured

Base of section . 
NORTH OF CA NONCITO section, E1/2, sec, $34, T, 11 \mathrm{~N}, \mathrm{R}, 3 \mathrm{~W}$,

(Measured by V. L. Freeman, October 1954)

Feet

Top of measured section.

Dakota sandstone:

Not measured or described.

\section{Morrison formation:}

Brushy Basin member:

Claystone, sandy, light greenish gray (5G8/1), minor amounts of sandstone and limy nodules, forms frothy surface. Poorly exposed, especially near top . . . . . . . . 176.0

Sandstone, yellowish gray (5Y8/1), medium-grained, moderately sorted, subrounded, grains of clay coated quartz with orange, black, and white accessory grains, quartz. clay, and calcite cement; bedding indistinct but in part is crossbedded on medium scale . . . . . . . . . . . . . . . . . . .

Claystone, sandy and sandstone, clayey, yellowish gray (5Y8/1) to light brownish gray (5YR6/1) with minor greenish tint; some limy nodules and chert; forms slightly

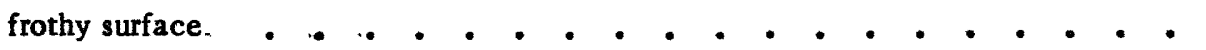

Gradational contact.

Recapture member (probably includes equivalents to Westwater Canyon member):

Sandstone, partly clayey, yellowish gray $(5 Y 8 / 1)$ with limonite stains near base, fine- to medium-grained, moderately sorted; friable, calcareous especially near base; bedding not visible 
NORTH OF CAÑNONCITO section--Continued

Morrison formation--Continued

Feet

Glaystone, very sandy (to medium-grained), grayish red (10R4/2), calcareous. Unit

contains one thin hard green sandstone bed; forms slightly frothy surface.$\quad$. $-\quad 24.2$

Sandstone, moderate orange pink (5YR8/4) to yellowish gray (5Y8/1), medium-grained,

poorly sorted, rounded, grains of quartz with uncommon black and orange accessory

grains; friable, calcareous cement and uncommon specks of unknown white cement;

crossbedding is small to medium scale . . . . . . . . . . . . 10.1

Claystone, very sandy and sandstone, clayey; grayish red (10R4/2), calcareous; sandstone

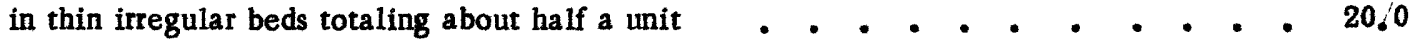

Sandstone, yellowish gray (5Y8/1), medium-grained, moderately sorted, rounded, grains

of quartz with common black, orange, red, and white accessory grains; alternating

hard and friable zones, calcite cement; bedding not visible $. . . \quad . \quad . \quad . \quad 5.4$

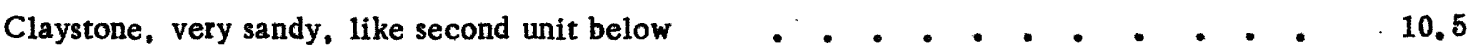

Sandstone, yellowish gray (5Y8/1), fine-grained, poorly sorted, rounded, grains of quartz

with uncommon orange, red, black, and white accessory grains; slightly friable,

calcareous; structureless; common limonite staining. Unit grades into unit above $\quad$ - $\quad 18.0$

Claystone, very sandy (to medium-grained), grayish red (10R4/2), calcareous, several

irregular thin beds of sandstone . . . . . . . . . . . . . . 12.6

Total Recapture member and probable equivalents of Westwater Canyon member . $\quad 115.3$

Base of measured section.

Bluff sandstone (part):

Sandstone, grayish yellow (5Y 7/4), fine-grained, well-sorted, rounded, grains of quartz

with black, white, and orange accessory grains; friable; bedding indistinct but in

part is extremely large scale crossbedding . . . . . . . . . Not measured 
RED BLUFF section, $W 1 / 2$, sec, $3, T, 12 \mathrm{~N}, \mathrm{R}, 9 \mathrm{~W}$.

(Measured by V. L. Freeman and L. S. Hilpert, August 1954)

Feet

Top of measured section

Dakota sandstone (part):

Sandstone, very pale orange (10YR8/2), to dark yellowish orange (10YR6/6), the yellow coloring caused by limonite staining generally along bedding, medium-grained, poorly sorted with local scattered granules and pebbles of red and black chert and vein quartz. subangular to rounded, grains of quartz with rare chert and white accessory grains; abundant quartz overgrowths; parallel bedded with some tabular crossbedding .

49.0

\section{Morrison formation:}

Brushy Basin member:

Claystone and sandstone, clayey, poorly exposed; greenish gray (5GY6/1) at base and pale olive (10Y6/2); local calcareous thin-bedded sandstone lenses, greenish gray (5GY6/1).

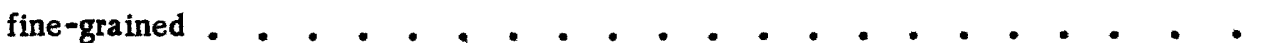

88.0

Sandstone, pale yellowish brown (10YR7/2), medium- to coarse-grained, poorly sorted with local granules and small pebbles, subangular to rounded, grains of quartz with uncommon orange and black accessory grains; crystal calcite cement at top and specks of unknown white cement throughout; cross-laminationiare medium scale and low

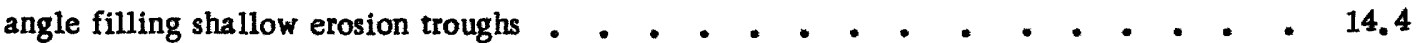

Mostly covered; some claystone, yellowish gray (5Y8/1) and light greenish gray (5GY8/1) . free of sand grains, some limy nodules, some seams of gypsum $\quad$ - $\quad$ - $\quad$ - $\quad$ - 42.6 
RED BLUFF section--Continued

Morrison formation--Continued

Brushy Basin member---Continued

Feet

Sandstone, yellowish gray (5Y8/1), medium-grained, poorly sorted, rounded grains

of quartz with white, black., green, and orange accessory grattis; friable, calcareous; forms surface coated by small nodules . . . . . . . . . . . . 4.0

Claystone, slightly sandy, grayish yellow green ( $5 G$ Y7/2) and light grayish red (10R5/2) in lower part, common limy nodules . . . . . . . . . . . 10.6

Total Brushy Basin member $\quad$ • . . . . . . . . . . . 159.2

Westwater Canyon member:

Sandstone, grayish orange (10YR7/4) with widespread limonite specks, medium- to coarsegrained, moderately to poorly sorted with scattered granules, subrounded, grains of quartz with common white (kaolin?) and rare black (chert?) accessory grains; friable, local crystal calcite cement; cross-laminations are medium scale and low angle between planar erosion surfaces. Locally claystone, pale yellowish green (10G Y $7 / 2)$

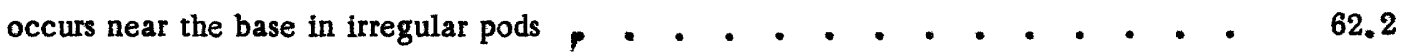
Total Westwater Canyon member _. . . . . . . . . 62.2

Recapture member:

Sandstone, clayey and some claystone, sandy, dusky red purple (5RP3/2) and greenish gray (5G Y6/1), sandstone in fine-grained, claystone locally contains limy nodules; unit forms

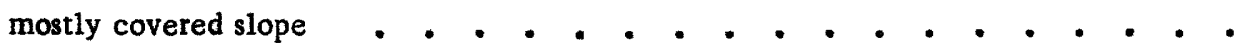

Sandstone, light yellowish gray (5Y9/1), fine- to coarse-grained, local conglomeratic lenses with pebbles dominantly of chert, moderately to poorly sorted, subrounded, grains of quartz with white, orange and black accessory grains; crystal calcite cement; crossbedding filling scours 


\author{
RED BLUFF section--Continued \\ Morrison formation--Continued \\ Westwater Canyon member--Continued
}

Feet

Sandstone, clayey and claystone, sandy, mostly light greenish gray (5G Y8/1) and brownish gray (5YR4/1) with some grayish red purple (5RP4/2) and dusky yellow (5Y6/4); sandstone is fine-grained and poorly sorted; local limy nodules. . . . . . . . .

Sandstone, light yellowish gray (5Y9/1), mediurn-grained, poorly sorted, rounded, grains of ; quartz with white and orange accessory grains, scattered granules and green clay chips; friable, locally calcareous; bedding obscrure; weathers to rounded ledge . . .

Sandstone, clayey, very dusky red purple (5RP2/2), very fine- to fine-giained, moderately sorted, grains of quartz with black and orange accessory grains; local small limy nodules. Unit contains local thin beds of sandstone, greenish gray (10G Y5/2); hard, clay cement . . . . . . . . . . . . . . . . . .

Sandstone, light yellowish gray (5Y9/1) and very light greenish gray (5GY9/1), fine- to medium-grained, poorly sorted, subroundec, grains of quartz with white, orange, red, green, and black accessory grains; friable; crossbedding is small to medium scale and low angle in tabular sets between planar erosion surfaces

Sandstone, lenticular with thin irregular lenses and pods of claystone; claystone, dark reddish brown (10R3/4) mottled light greenish gray (5GY8/1); sandstone, light pinkish gray (5YR9/1), medium- to coarse-grained with scattered granules, poorly sorted, subrounded to rounded, grains of quartz with orange and black accessory grains; friable, calcareous; crossbedding is small scale and low angle in wedge-shaped sets . . . 
RED BLUFF section--Continued

Morrison formation--Continued

Recapture member--Continued

Feet

Sandstone, light pinkish gray (5YR9/1), medium- to coarse-grained, with rare granules, poorly sorted, subrounded to rounded, grains of quartz and chert with white and orange accessory grains; friable; in part is parallel bedded and in part is crossbedded, medium scale, low angle. This unit fills a channel in underlying unit that is 2 to $4 \mathrm{ft}$, deep

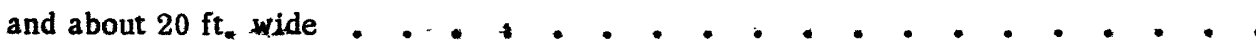

Sanđstone, slightly clayey, greenish gray (5GY6/1), medium-grained, moderately sorted,

rounded, grains of quartz with uncommon orange and red and rare black accessory

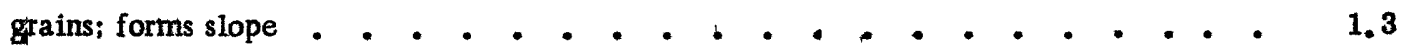

Claystone, slightly silty, very dusky red (10R2/8); some limy nodules and gypsum; forms :

rounded slope

Sandstone, slightly clayey, pale olive $(10 \mathrm{Y} 6 / / 2)$ with some limonite stains, fine- to medium-grained, moderately sorted, rounded, grains of quartz plus common orange and rare black accessory grains; very friable; forms slope. Unit appears

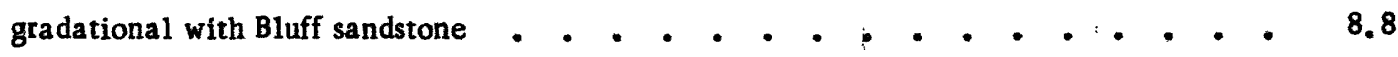

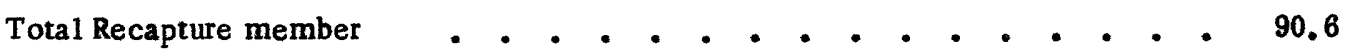

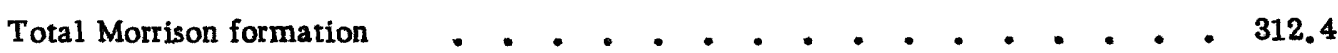

Bluff sândstờné (part):

Sandstoné, grayisk yetiow $(5 Y 8 \% 4)^{2}$, fine - to medium-grained; very friăbie, calcareous cdncretibns locally present; cross laminations are medium to large scale and high angle in wedge shaped sets Not measured Base of section 
SHEEP CAMP section, $S 1 / 2 \mathrm{sec}, 2, T, 8 \mathrm{~N}, 1, \mathrm{R}, 6 \mathrm{~W}$.

(Measured by V. L. Freeman, September 1954)

Feet

Top of measured section.

\section{Dakota sandstone (paxt);}

Sandstone, like basal Dakota unit, two silicified 6 in. bands, also a few very thin carbonaceous claystone partings . . . . . . . . . . . . . 15.0

Claystone, carbonaceous, sandy. Along strike unit becomes sandstone like below with very thin partings of carbonaceous claystone. Unit forms re-entrant in cliff $\quad$ - $\quad$ - 1.0 Sandstone, light yellow (5Y8/6), medium-grained, poorly sorted, granules common, rounded, grains of clay coated quartz with white (chert?) accessory grains; one 6 in: band is highly silicified and white; very thin crossbedding is medium scale and low angle. Plant remains present

Morrison formation:

Claystone, slightly fine-grained sandy, pale olive (10Y6/2) and minor grayish red purple; forms slightly frothy surface + . . . . . . . . . . . .

Sandstone, white (N9), medium-grained, well- to moderately sorted, subrounded, grains of quartz with orange and white accessory grains; slightly friable, calcareous cement; indistinct crossbedding is medium scale and low angle

Claystone, like second unit below with two thin beds of sandstone, like below, 


\section{SHEEP CAMP section---Continued}

Morrison formation--Continued

Feet

Sandstone, white (N9), medium-grained, well- to moderately sorted, subrounded,

grains of quartz with orange and white accessory grains; slightly friable. calcareous cement; indistinct crossbedding is medium scale and low angle . . . . . . . 4.6

Claystone, slightly fine-grained sandy, pale olive (10Y6/2) and minor grayish red purple;

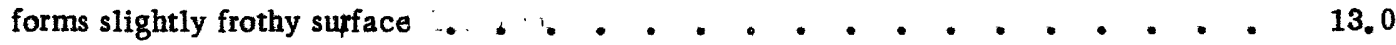
Sandstone, very light greenish gray ( $5 G$ Y8/1), fine- to medium-grained, well- to moderately sorted, subrqunded, grains of quartz with orange and white accessory grains; slightly friable, calcareous cement; crossbedding is medium scale and low angle. Uncommon limy nodules, Unit is lenticular and interfingers with unit above $\quad . \quad 8.5$ Sandstone, clayey, very dusky red (between $5 \mathrm{RP2} / 2$ and 10R2/2) and light greenish gray $(5 G$ Y $8 / 1)$ in about equal amounts in alternating bands, medium-grained, moderately sorted, subrounded, grains of quartz and rare orange accessory grains; hard when fresh; unit forms soft slope. Laterally init contains lens like unit above

Sandstone, clayey, dark reddish brown (10R3/5), fine-grained, moderately sorted, subrounded, grains of stained quartz with rare black accessory grains; hard when fresh; unit forms soft slope. Unit grades into Bluff sandstone and locally interfingers with Bluff . . . . . . . . . . . . . . . 3.7

Note: Lower two units of Morrison probably are equivalent to Recapture member and remainder probably equivalent to Brushy Basin member

Total Morrison formation . . . . . . . . . . . . . . 121.8 
SHEEP CAMP section--Continued

Morrison formation---Continued

Feet

Bluff Sandstone (part):

Sandstone, Kight greenish yellow (10Y7/2) slightly lighter near top, medium- and finegrained in gradationally alternating 6 in. beds, well to moderately sorted, subrounded to rounded, grains of green clay coated quartz with common white chert and rare orange accessory grains; friable, zones of heavy limonite cement. Poorly defined parallel bedding underlain by crossbedding of extremely large scale and low angle . . . . . . . . . . . . . . . . . Not measured

Base of section.

\section{NEW MEXICO - VALENCIA COUNTY}

WEST MESA GIGANTE section (composite).

(Measured by V. L. Freeman, September, October 1954)

Section A., sec, $10, T, 10$ N., R, 4 W.

Top of measured section

Dakota sandstone:

Not measured. Sandstone, conglomeratic, with minor carbonaceous shale. Siliceous cement.

Morrison formation:

Brushy Basin member:

Sandstone, yellowish gray ( $5 Y$ Y $8 / 1$ ) to white (N9), medium-grained, well to poorly sorted, subrounded to subangular, grains of clay coated quartz with rare pink and black accessory grains, green clay chips locally abundant but usually rare; fiable, some calcareous cement and specks of white unknown cement; crossbedding is medium scale and low angle filling shallow erosion troughs. This is "Jackpile" sandstone $\quad . \quad 90.9$ 
WEST MESA GIGANTE section A --Continued

Morrison formation--Continued

Brushy Basin member--Continued

Feet

Claystone, silty and siltstone, clayey, light greenish gray ( $5 G$ Y8/1) and minor grayish red (10R4/2), limy nodules common. Near top is $2 \mathrm{ft}$. bed of sandstone, clayey,

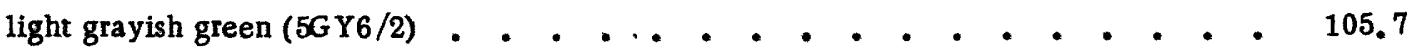

Sandstone, yellowish gray (5Y8/1), medium-grained, poorly sorted, subrounded to sub- . angular, grains of clay coated quartz with orange, red, black, and rare green accessory grains; granules and pebbles (to $1 / 2$ in.) scattered in sandstone, include feldspar; crossbedding is medium scale and low angle, filling shallow erosion troughs

Claystone, silty; siltstone and very fine sandstone, both very clayey; all light greenish gray (5G8/1), some hard calcareous beds, weathers to frothy surface . . . . 71.7 Sandstone, very pale orange(10YR8/2) to dark yellowish brown (10YR3/4), mediumgrained, moderately sorted, grains of quartz with green, orange, red, and black accessory grains; hard; crossbedding is medium scale and low angle. Three beds with clay chips at base of each . . . . . . . . . . . . . . 3.0

Siltstone and very fine sandstone; both clayey, pinkish gray (5YR8/1) and light greenish gray (5G Y8/1), calcareous; also claystone, silty, light greenish gray (5G Y8/1) and minor pale purple (5P6/2), hard, calcareous; some units weather to frothy surface . . $\quad 81.2$ Total Brushy Basin member $\quad$. . . . . . . . . . . . 372.5 
WEST MESA GIGANTE section---Continued

Section $B, S W-1 / 4$ of $\sec , 23, T, 10 \mathrm{~N},, \mathrm{R}, 4 \mathrm{~W}$.

Morrison formation--Continued

Westwater Canyon member:

Feet

Sandstone, very pale orange (10YR8/2) to disky yellow (5Y6/4), medium- to coarsegrained, poorly to moderately sorted, subrounded to angular, grains of quartz and feldspar (angular and up to granules in size) with common red and white (chert?) accessory grains; some beds clayey; friable except for local crystal calcite cement. Indistinct crossbedding . . . . . . . . . . . . . . . . .

Sandstone (75\%) and claystone with limy nodules (25\%); sandstone, very pale orange (10YR8/2), medium- to coarse-grained, moderately sorted, rounded to subrounded, grains of quartz and feldspar with common red and white and uncommon green and gray accessory grains; friable, calcareous, locally crystal calcite cement; crossbedding is small to medium scale, low angle, lenticular type; claystone like below but pale purple (5P7/2) in color and with large ( $1 \mathrm{ft}$.) nodules that form bed

On Section A where base is not exposed Westwater Canyon is $62 \mathrm{ft}$. thick.

\section{Recapture member:}

Claystone, slightly- fine-grained sandy, light greenish gray $(5 G 8 / 1)$ with purplish tints locally; limy nodular beds total $2,0 \mathrm{ft}$. Claystone is slightly calcareous . . .

Sandstone, very clayey, pale yellowish green $(10 G \mathrm{Y} 7 / 2)$ in middle $1 / 3$, rest is grayish red purple (5RP4/2). Medium-grained, poorly sorted, rounded, grains of quartz with common orange and red and rare black and white accessory grains. Purple part is calcareous. Bedding obscure . . . . . . . . . . . . 
WEST MESA GIGANTE section B--Continued

Morrison formation--Continued

Recapture member:-Continued

Feet

Claystone, very sandy (fine-grained) (50\%) and sandstone (50\%): claystone, reddish brown (10R4/4), slightly calcareous but not containing limy nodules here; sandstone, yellowish gray, medium-grained, moderately sorted, rounded, grains of quartz with uncommon orange, black, and red accessory grains; bedding obscure. Sandstone and claystone thickly ( 2 to $3 \mathrm{ft}$.) interbedded. Claystone beds weather to slightly frothy surface . . . . . . . . . . . . . . . 31.6 Total Recapture member _. . . . . . . . . . . . . 45.7 Base sof measured section.

Bluff sandstone (part):

Sandstone, grayish yellow (5Y8/4) to moderate yellow $(5 Y 7 / 6)$, medium-grained, well to moderately sorted, rounded grains of quartz with black, orange, and white accessory grains; friable, local crystal calcite cement. Crossbedding is large scale and poorly defined . . . . . . . . . . . . . . . . Not measured 